\title{
Physical and sexual violence, childhood sexual abuse and HIV/STI risk behaviour among alcohol- using women engaged in sex work in Mongolia
}

\author{
Angela M. Parcesepe, Aira Toivgoo, Mingway Chang, Marion Riedel, \\ Catherine Carlson, Rebecca DiBennardo \& Susan S. Witte
}

To cite this article: Angela M. Parcesepe, Aira Toivgoo, Mingway Chang, Marion Riedel, Catherine Carlson, Rebecca DiBennardo \& Susan S. Witte (2015) Physical and sexual violence, childhood sexual abuse and HIVISTI risk behaviour among alcohol-using women engaged in sex work in Mongolia, Global Public Health, 10:1, 88-102, DOI: 10.1080/17441692.2014.976240

To link to this article: https://doi.org/10.1080/17441692.2014.976240

曲 Published online: 10 Nov 2014.

Submit your article to this journal $₫$

Џ Article views: 156

Q View related articles $\llbracket$

View Crossmark data $\nearrow$

Citing articles: 5 View citing articles $\asymp$ 


\title{
Physical and sexual violence, childhood sexual abuse and HIV/STI risk behaviour among alcohol-using women engaged in sex work in Mongolia
}

\author{
Angela M. Parcesepe ${ }^{\mathrm{a} *}$, Aira Toivgoo ${ }^{\mathrm{b}}$, Mingway Chang ${ }^{\mathrm{c}}$, Marion Riedel ${ }^{\mathrm{d}}$, \\ Catherine Carlson ${ }^{\mathrm{e}}$, Rebecca DiBennardo ${ }^{\mathrm{f}}$ and Susan S. Witte ${ }^{\mathrm{c}}$ \\ ${ }^{a}$ Gillings School of Global Public Health, University of North Carolina at Chapel Hill, Chapel Hill, \\ NC, USA, ${ }^{b}$ Wellspring NGO, Ulaanbaatar, Mongolia; ${ }^{c}$ Social Intervention Group, Columbia \\ University School of Social Work, New York, NY, USA; ${ }^{d}$ Columbia University School of Social \\ Work, New York, NY, USA; ${ }^{e}$ Columbia University/New York State Psychiatric Institute, New York, \\ NY, USA; ${ }^{f}$ Department of Sociology, University of California at Los Angeles, Los Angeles, CA, USA
}

(Received 10 September 2013; accepted 13 September 2014)

\begin{abstract}
Although the prevalence of human immunodeficiency virus (HIV) in Mongolia is low, it could increase without strategic prevention strategies. Female sex workers (FSWs) often experience barriers to prevention, including interpersonal violence. This study investigated if childhood sexual abuse (CSA) or recent physical or sexual violence was associated with HIV sexual risk behaviours and if CSA modified associations between recent violence and HIV sexual risk behaviours. Two-hundred twenty-two women who (1) were at least 18 years old and clients at the National AIDS Foundation; (2) reported vaginal or anal sex in the past 90 days in exchange for money or goods and (3) met criteria for harmful alcohol use in the past year were enrolled. In-person interviews assessed sexual risk behaviours and violence in childhood and adulthood. Negative binomial regression, ordinary least squares regression and modified Poisson regression were performed. Sexual risk with paying partners was associated with penetrative CSA and sexual violence by paying partners. CSA and recent violence were not associated with sexual risk behaviours with intimate partners. CSA modified the association between recent sexual violence and unprotected sex with intimate partners. Findings highlight the need for integrated violence and sexual risk reduction services to ensure safe and effective prevention for FSWs.
\end{abstract}

Keywords: violence; HIV; alcohol; sex work

\section{Introduction}

Although the prevalence of human immunodeficiency virus (HIV) in Mongolia is low, Mongolia is at high risk of experiencing an HIV epidemic if rapid and strategic HIV prevention strategies are not instituted (UNGASS, 2010). One hundred cases of HIV have officially been reported, representing less than $0.1 \%$ of the adult population (Joint United Nations Programme on HIV/AIDS [UNAIDS] Mongolia, 2012). This represents a significant increase from just five reported cases as of 2004 (UNAIDS Mongolia, 2012).

A constellation of factors makes Mongolia vulnerable to rapid HIV spread. Mongolia is bordered by Russia to the North and China to the South and East, two countries with

*Corresponding author. Email: angela_parcesepe@unc.edu 
increasing numbers of people living with HIV/acquired immune deficiency syndrome (AIDS). Of new HIV infections in Eastern Europe and Central Asia, almost 90\% occur in Russia or the Ukraine (UNAIDS, 2011). In China, while national HIV prevalence remains low, the number of people living with HIV/AIDS continues to increase (Ministry of Health of the People's Republic of China, 2012). Moreover, groups at elevated risk of contracting HIV in China (e.g. female sex workers [FSWs], men who have sex with men) report high rates of HIV sexual risk behaviours (Ministry of Health of the People's Republic of China, 2012). A regional highway is under construction in Mongolia. Once completed, this highway will provide a trade route between Russia and China through Mongolia, likely increasing the migration of workers through Mongolia. Increased migration of workers has been associated with growing HIV epidemics across geographic boundaries on other continents (Elbright, Altantsetseg, \& Oyungerel, 2003; Fages, 1999; Hagan \& Dulmaa, 2007; UNAIDS, 2001).

In addition, since 1990 Mongolia has experienced a difficult economic transition from a centrally planned (Soviet-supported) to a free market economy, resulting in $27 \%$ of the population living below the poverty line (World Bank, 2013). Mongolia has a total population of 2.8 million, $40 \%$ of whom live in the capital city of Ulaanbaatar (World Bank, 2013). Ulaanbaatar has experienced increased alcoholism, unemployment and homelessness, a deteriorating health and social services system, and substantial increases in survival sex work among women (Davaalkham et al., 2009; National AIDS Foundation [NAF], 2001, 2003; Purevdawa et al., 1997). Sex work remains illegal in Mongolia, according to the 1998 Mongolian Law against Pornography and Prostitution which banned the organisation and facilitation of prostitution (Carlson, Tsai, Aira, Riedel, \& Witte, in press). Despite this law, there are approximately 4000 commercial sex workers in Ulaanbaatar, the majority of whom are females (UNICEF, 2006). The number of women engaging in sex work in Mongolia fluctuates seasonally with many women engaging in sex work only during warmer summer months (Carlson et al., in press).

In Mongolia, HIV primarily remains clustered among high-risk groups including FSWs and men who have sex with men. Although the most recent Behavioural Surveillance Survey reported a 0\% prevalence of HIV among FSWs surveyed, half of all reported female cases of HIV are among FSWs whose paying partners are considered a bridge population in Mongolia (UNAIDS Mongolia, 2012). Because rates of new sexual partner acquisition among FSWs are significantly higher than the general population, FSWs often serve as drivers of HIV in low prevalence settings, contributing disproportionately to the spread of HIV into the general population (Anderson, 1999; Morris \& Ferguson, 2006; World Health Organization [WHO], 2011). Given the transmission dynamics of HIV, FSWs are uniquely positioned to prevent a generalised HIV epidemic in low prevalence settings such as Mongolia.

Alcohol use among FSWs is prevalent and normative across countries and commonly used by FSWs to facilitate participation in commercial sex. FSWs are often encouraged or coerced to drink alcohol by clients and pimps (Markosyan et al., 2007). FSWs often report using alcohol while looking for clients and having sex while intoxicated (Chersich et al., 2007; Markosyan et al., 2007; Nishigaya, 2002; Rogers, Ying, Xin, Fung, \& Kaufman, 2002). Alcohol use has been consistently associated with violence and HIV risk behaviours among FSWs including unprotected sex, anal sex, sexually transmitted infections (STIs) and HIV (Chersich et al., 2007; Li, Li, \& Stanton, 2010; Scorgie et al., 2012; Wechsberg, Luseno, \& Lam, 2005; Wechsberg, Luseno, Lam, Parry, \& Morojele, 2006; WHO, 2011; Yadav et al., 2005). 
Studies of sex workers across the globe highlight that multiple traumas, including childhood sexual abuse (CSA) and intimate partner violence (IPV), are associated with HIV sexual risk behaviours among this population (El-Bassel et al., 2003; Paone, Cooper, Alperen, Shi, \& Des Jarlais, 1999; Shahmanesh et al., 2009; Surratt, Kurtz, Weaver, \& Inciardi, 2005; Ulibarri et al., 2009). FSWs are at particularly high risk of physical and sexual violence from paying and non-paying partners, managers and the police (Decker et al., 2010; Karandikar \& Prospero, 2010; Open Society Institute, 2009; Rhodes, Simic, Baros, Platt, \& Zikic, 2008; Simic \& Rhodes, 2009; Swain, Saggurti, Battala, Verma, \& Jain, 2011). Violence has been consistently associated with increased HIV risk among FSWs, including increased risk of STIs, anal sex and unprotected sex (Decker et al., 2012; Simic \& Rhodes, 2009; Swain et al., 2011; Ulibarri et al., 2011).

Experiences of violence contribute significantly to increasing women's risk of HIV acquisition through biological, behavioural and social mechanisms (Adimora et al., 2013; El-Bassel et al., 2003; Surratt et al., 2005). Violence is often linked to conflicts over condom negotiation (Wingood, Hunter-Gamble, \& DiClemente, 1993). Coercive sex puts women at increased risk of contracting an STI, as they have less control over the situation and safe sexual practices. STIs, in turn, enhance the probability of HIV transmission during unprotected sex (Choi, Chen, \& Jiang, 2008). The prevalence of STIs is high and increasing in Mongolia (Davaalkham et al., 2009; Hagan \& Dulmaa, 2007). STIs are currently the most prevalent type of communicable disease in Mongolia (UNGASS, 2010).

Research on violence against FSWs in Mongolia remains limited. One study examined the prevalence of violence among FSWs in Mongolia before and after implementing a risk reduction intervention. At baseline, across intervention groups, 38$52 \%$ of FSWs reported recent physical violence from an intimate partner, 50-62\% reported recent physical violence from a paying partner, $12-16 \%$ reported recent sexual violence from an intimate partner and $26-36 \%$ reported recent sexual violence from a paying partner (Carlson et al., 2012).

In addition to violence during adulthood, FSWs are more likely to have experienced CSA compared with women not engaged in sex work (Foti, 1995; James \& Meyerding, 1977; Potter, Martin, \& Romans, 1999). CSA has been associated with HIV sexual risk behaviours, including multiple sexual partners, unprotected sex, anal sex, STI symptoms and early sexual debut (Lalor \& McElvaney, 2010). In addition, women who experience CSA are at increased risk of sexual violence in adulthood from intimate partners (Classen, Palesh, \& Aggarwal, 2005; Dunkle et al., 2004; Fanslow, Robinson, Crengle, \& Perese, 2007; Fergusson, Horwood, \& Lynskey, 1997; Messman-Moore \& Long, 2003).

Given that violence is highly prevalent among FSWs and associated with HIV sexual risk behaviours, greater understanding of the nature of these relationships is needed. Recent evidence indicates that, among FSWs, HIV risk may differ by type of violence. For example, among FSWs in Moscow, violence perpetrated by paying clients, but not pimps, was associated with increased STI prevalence (Decker et al., 2012). In addition, despite the high prevalence of both CSA and recent violence against FSWs, little is known about the combined influence of CSA and recent violence on sexual risk behaviours. More specifically, whether CSA interacts with recent sexual or physical violence to further increase FSWs' risk of engaging in sexual risk behaviours remains understudied. Greater understanding of interactions between violence during childhood and adulthood with sexual risk behaviours is needed to develop effective and appropriate HIV prevention strategies for FSWs, particularly for those with extensive histories of violence. Such information can be used to inform more relevant HIV prevention 
intervention components targeting FSWs and avoid escalation of HIV transmission in other countries at similarly high risk of experiencing an HIV epidemic, particularly countries with rapidly growing economies like Mongolia.

The purpose of this study is to investigate whether (1) CSA is associated with HIV sexual risk behaviours; (2) recent physical or sexual violence is associated with HIV sexual risk behaviours and (3) CSA modifies the association between recent violence and HIV sexual risk behaviours among FSWs in Mongolia.

\section{Methods}

\section{Sample}

Data were collected from women receiving services at the NAF in Ulaanbaatar, Mongolia. Founded in 2000, NAF is the central resource and distribution source for non-governmental organization education and training in HIV/STI risk reduction and transmission information in Mongolia. Data are part of a parent study recruiting women for a randomised clinical trial testing the efficacy of an HIV/STI prevention intervention to reduce alcohol abuse and sexual risk behaviours among FSWs (Witte et al., 2011).

A total of 270 women were recruited and screened from 2008 to 2009. Women were eligible for the study if they (1) were at least 18 years of age; (2) were currently enrolled in the NAF programme; (3) reported having engaged in vaginal or anal sexual intercourse in the past 90 days in exchange for money, alcohol or other goods; and (4) met criteria for harmful alcohol use in the past year (score of 8 or above on the Alcohol Use Disorders Identification Test [AUDIT], an internationally validated screening measure for alcohol problems in the past year, where a score of at least 8 or more indicates hazardous or harmful alcohol consumption) (Saunders, Aasland, Babor, DeLaFuente, \& Grant, 1993). Of those screened, 41 women were excluded because they did not meet one or more of the eligibility criteria. Of the remaining 229 eligible women, 222 (97\%) completed informed consent and baseline interviews. Research assistants administered baseline surveys lasting 60-90 minutes in a private setting. Assessments were administered using a computer-assisted personal interviewing method.

\section{Assessment}

The assessment interview was designed to elicit self-reported data. Measures were translated into Mongolian from English and then back-translated for accuracy. The assessment was pilot tested with seven NAF and research project staff and determined to have adequate face validity.

\section{Socio-demographics}

Socio-demographic variables included age, race/ethnicity, education, employment status, income, marital status, having an intimate partner, current housing situation and whether exchanging sex for money was the primary source of income.

\section{Sexual risk behaviours}

Using a method consistent with the Timeline Followback, participants provided data on the proportion and number of times they engaged in unprotected vaginal and anal sex with paying partners and intimate partners in the past 90 days (Sobell \& Sobell, 1992). Measures were assessed separately for paying and intimate partners. A paying partner 
was defined as someone with whom you have sex in exchange for money, alcohol or other goods. An intimate partner was defined as a spouse, boyfriend, lover or regular sexual partner who is not a paying partner.

\section{Physical and sexual violence}

To examine IPV as well as violence related to sex work, an adaptation of the Revised Conflict Tactics Scale was used which combined questions from similar categories (moderate vs. severe) assessing lifetime and recent physical and sexual violence perpetrated by intimate or paying partners (Straus, Hamby, Boney-McCoy, \& Sugarman, 1996). 'Mild' violence questions, psychological aggression and negotiating behaviours were dropped to reduce questionnaire length. Recent violence was defined as violence that occurred within the past 90 days. The Cronbach's alpha for the modified scale was 0.75 and 0.76 when measuring violence from intimate and paying partners, respectively.

\section{Childhood sexual abuse}

CSA was measured using a modified version of the Childhood Sexual Abuse Interview (CSAI). The modified CSAI consisted of 7 of the original 11 items which assessed experiences with someone at least 5 years older than the respondent, ranging from an attempt to have intercourse to forced intercourse. Exposure variables considered less severe and perhaps with less face validity in the Mongolian context were dropped. Each item was scored by assigning ' 1 ' for the presence or ' 0 ' for the absence of the item. Any CSA was measured by summing the seven items. A summed score of 0 was coded as no CSA; a summed score greater than 0 was coded as positive for any CSA. Penetrative CSA was quantified using four items from the CSAI (i.e. did anyone ever put his penis in your mouth or put their mouth on your private sexual parts, have intercourse with you against your will, insert an object into your vagina or put their penis or object in your bottom?) (Finkelhor, 1978; Sgroi, 1982). A summed score of 0 on these four items was coded as no penetrative CSA; a summed score greater than 0 on these four items was coded as positive for penetrative CSA. The Cronbach's alpha for the modified scale was 0.72 .

\section{Data analysis}

Data were collected using a computer-assisted data entry program. A faulty gate question to a single section of the assessment was discovered that affected the first 30 participants. Sexual risk variables with paying partners were missing for these participants. Bivariate analyses were conducted comparing those with and without missing data. There were no significant differences between groups in relation to reported alcohol use, sexual risk with trust partners or experiences of violence. However, those with missing data were significantly younger than those without missing data. No other significant sociodemographic differences were identified. Because the dates that participants completed the assessment were not conditioned on any particular variable, data were missing at random and multiple imputation was performed to complete the dataset prior to analyses (Rubin, 1987).

Univariate statistics were used to describe socio-demographic characteristics, sexual behaviours, frequency and types of violence. Negative binomial regression was performed to estimate the incidence rate ratio (IRR) of unprotected vaginal and anal sex in the past 90 days. Ordinary least squares regression was performed to estimate the $b$ 
coefficient of the proportion of unprotected vaginal or anal sex in the past 90 days. Modified Poisson regression was performed to estimate the relative risk reduction (RRR) of the prevalence of unprotected vaginal or anal sex in the past 90 days. All analyses were adjusted for age, education, income, marital status and alcohol use and performed separately for intimate and paying partners. Effect measure modification of the association between recent violence and HIV sexual risk behaviour by CSA was assessed by examining the magnitude and significance of product terms between recent physical or sexual violence and CSA.

\section{Results}

\section{Socio-demographics}

Descriptive statistics for the study sample are provided in Table 1. The average age of respondents was 34 years (range: 18-67); the average age of initiation of sex work was 28 years (range: 14-50). Participants were relatively well educated with $64 \%$ having completed secondary school. Almost all (99\%) participants were unemployed in formal sectors and reported sex work as their main form of income (93\%). Most (60\%) participants reported being divorced, widowed or separated. Forty-four per cent of respondents reported currently having an intimate partner. Because eligibility was limited to women who scored 8 or higher on the AUDIT, all women in the sample were alcohol users. The overwhelming majority (93\%) of women screened positive for alcohol dependence (i.e. scored 20 or greater on AUDIT).

\section{Violence and abuse in childhood and adulthood}

Experiences of sexual abuse during childhood were common (Table 1). Over half of women surveyed (55\%) reported having experienced CSA; $41 \%$ reported having experienced penetrative CSA.

Experiences of sexual and physical violence in adulthood were also common. Paying and intimate partners were reported to have perpetrated sexual and physical violence against respondents. However, violence perpetrated by paying partners was more common. Eighty-four per cent of respondents reported physical violence from paying partners with over half (58\%) reporting such violence recently. Over half of respondents $(52 \%)$ reported sexual violence from paying partners with $35 \%$ reporting such violence recently.

The prevalence of physical and sexual violence perpetrated by intimate partners was also high. Fifty-nine per cent of respondents reported physical violence from an intimate partner, with 54\% reporting recent physical violence. Twenty-two per cent reported sexual violence from an intimate partner, with $17 \%$ reporting such violence recently.

\section{Sexual risk behaviours}

Engaging in unprotected sex with paying and intimate partners was common among FSWs surveyed (Table 2). Seventy per cent of respondents reported recent unprotected vaginal or anal sex with paying partners with $18 \%$ reported recent unprotected anal sex with paying partners. Respondents reported unprotected vaginal or anal sex with paying partners an average of 34 times in the past 90 days (standard deviation $[\mathrm{SD}]=57$ ). Ninety per cent of respondents reported recent unprotected vaginal or anal sex with intimate partners, with $10 \%$ reporting recent unprotected anal sex with intimate partners. 
Table 1. Socio-demographic characteristics of sample.

\begin{tabular}{|c|c|c|}
\hline Variable & $\begin{array}{l}\text { Frequency/mean } \\
\qquad(N=222)\end{array}$ & \\
\hline Age & Mean: 34.28 , range: $18-67$ & \\
\hline \multicolumn{3}{|l|}{ Education (highest grade completed) } \\
\hline No formal schooling & $0.9 \%(n=2)$ & \\
\hline Less than secondary school & $11.3 \%(n=25)$ & \\
\hline $\begin{array}{l}\text { Secondary or upper-secondary } \\
\text { school }\end{array}$ & $64.4 \%(n=143)$ & \\
\hline Some college or university & $8.6 \%(n=19)$ & \\
\hline $\begin{array}{l}\text { Technical education or } \\
\text { vocational Training }\end{array}$ & $9.5 \%(n=21)$ & \\
\hline 4-year college diploma & $5.4 \%(n=12)$ & \\
\hline \multicolumn{3}{|l|}{ Employment status } \\
\hline Unemployed & $99.1 \%(n=220)$ & \\
\hline \multicolumn{3}{|l|}{ Monthly income } \\
\hline$\leq 100,000$ togrogs $/ \mathrm{mth}^{\mathrm{a}}$ & $46.4 \%(n=103)$ & \\
\hline $\begin{array}{l}\text { Exchanging sex for money main } \\
\text { source of income (Yes) }\end{array}$ & $93.2 \%(n=206)$ & \\
\hline Age of initiation into sex work & Mean: 27.88 ; range: $14-50$ & \\
\hline \multicolumn{3}{|l|}{ Marital status } \\
\hline Single/never married & $31.5 \%(n=70)$ & \\
\hline Married & $9.0 \%(n=20)$ & \\
\hline Divorced/widowed/separated & $59.5 \%(n=132)$ & \\
\hline Intimate partner (Yes) & $44.1 \%(n=98)$ & \\
\hline \multicolumn{3}{|l|}{ Alcohol use } \\
\hline Harmful (AUDIT 8-15) & $3.2 \%(n=7)$ & \\
\hline Hazardous (AUDIT 16-19) & $4.1 \%(n=9)$ & \\
\hline Dependence (AUDIT $\geq 20$ ) & $92.8 \%(n=206)$ & \\
\hline \multicolumn{3}{|l|}{ Childhood sexual abuse } \\
\hline Any childhood sexual abuse & $55 \%(n=123)$ & \\
\hline $\begin{array}{l}\text { Penetrative childhood sexual } \\
\text { abuse }\end{array}$ & $41 \%(n=90)$ & \\
\hline \multicolumn{3}{|l|}{ Violence in adulthood } \\
\hline & $\begin{array}{l}\text { By paying partner } \\
(N=222) n(\%)^{\mathrm{b}}\end{array}$ & $\begin{array}{l}\text { By intimate partner } \\
(N=98) n(\%)^{\mathrm{c}}\end{array}$ \\
\hline Lifetime physical violence & $186(84 \%)$ & $58(59 \%)$ \\
\hline Lifetime sexual violence & $116(52 \%)$ & $22(22 \%)$ \\
\hline Recent physical violence & $129(58 \%)$ & $53(54 \%)$ \\
\hline Recent sexual violence & $78(35 \%)$ & $17(17 \%)$ \\
\hline
\end{tabular}

${ }^{\mathrm{a}}$ One US dollar is approximately 1250 Togrogs; 100,000 Togrogs is approximately US\$80.

${ }^{\mathrm{b}}$ Among all women.

${ }^{\mathrm{c}}$ Among women with intimate partners.

Respondents reported unprotected vaginal or anal sex with intimate partners an average of 35 times in the past 90 days $(\mathrm{SD}=70)$.

\section{Associations between unprotected intercourse and violence among paying partners}

Sexual risk taking with paying partners was associated with penetrative CSA and recent sexual violence by paying partners (Table 3$)^{1}$ 
Table 2. Frequency of sexual behaviours with intimate and paying partners.

\begin{tabular}{|c|c|c|}
\hline Sexual behaviours & $\begin{array}{l}\text { With paying partners } \\
\qquad(N=222)^{\mathrm{a}}\end{array}$ & $\begin{array}{l}\text { With intimate partners } \\
\qquad(N=98)^{\mathrm{b}}\end{array}$ \\
\hline $\begin{array}{l}\text { Number of times of } \\
\text { vaginal and anal sex in } \\
\text { the past } 90 \text { days }\end{array}$ & $\begin{array}{l}\text { Mean }=105.01(\mathrm{SD}=118.27) \\
\text { median }=72\end{array}$ & $\begin{array}{c}\text { Mean }=42.36(\mathrm{SD}=71.08) ; \\
\text { median }=24\end{array}$ \\
\hline $\begin{array}{l}\text { Number of times of } \\
\text { unprotected vaginal and } \\
\text { anal sex in the past } \\
90 \text { days }\end{array}$ & $\begin{array}{l}\text { Mean }=33.91(\mathrm{SD}=56.58) \\
\text { median }=10.5\end{array}$ & $\begin{array}{l}\text { Mean }=34.80(\mathrm{SD}=70.31) \\
\text { median }=19.5\end{array}$ \\
\hline $\begin{array}{l}\text { Proportion of unprotected } \\
\text { vaginal and anal sex in } \\
\text { the past } 90 \text { days }\end{array}$ & Mean $=0.30(\mathrm{SD}=0.31)$ & Mean $=0.75(\mathrm{SD}=0.36)$ \\
\hline $\begin{array}{l}\text { Any unprotected vaginal } \\
\text { or anal sex in the past } \\
90 \text { days }\end{array}$ & $156(70 \%)$ & $88(90 \%)$ \\
\hline $\begin{array}{l}\text { Any unprotected vaginal } \\
\text { sex in the past } 90 \text { days }\end{array}$ & $148(67 \%)$ & $87(89 \%)$ \\
\hline $\begin{array}{l}\text { Any anal sex in the past } \\
90 \text { days }\end{array}$ & $56(25 \%)$ & $13(13 \%)$ \\
\hline $\begin{array}{l}\text { Any unprotected anal sex } \\
\text { in the past } 90 \text { days }\end{array}$ & $41(18 \%)$ & $10(10 \%)$ \\
\hline
\end{tabular}

${ }^{a}$ Among all women.

${ }^{\mathrm{b}}$ Among women with intimate partners.

Women who reported penetrative CSA were 1.20 times $(95 \%$ confidence interval [CI]: $1.01,1.42$ ) as likely as women who did not report penetrative CSA to have engaged in recent unprotected vaginal or anal sex with paying partners, after controlling for age, education, income, marital status and alcohol use. In adjusted analyses, recent sexual violence from paying partners was associated with increased sexual risk taking with paying partners across all models. Recent sexual violence from paying partners was significantly positively associated with having engaged in recent unprotected vaginal or anal sex with paying partners, the proportion of recent vaginal or anal sex acts with paying partners that was unprotected and the total number of recent unprotected vaginal or anal sex acts with paying partners.

\section{Associations between unprotected intercourse and violence among intimate partners}

CSA and recent physical or sexual violence were not significantly associated with recent sexual risk behaviours with intimate partners, after adjusting for covariates (Table 4).

\section{Effect modification by CSA of association between recent violence and HIV sexual risk behaviours}

There were no statistically significant interactions between CSA and recent physical or sexual violence with paying partners (data not shown) at the $p<0.10$ level of significance. CSA significantly modified the association between recent sexual violence and recent unprotected vaginal or anal sex with intimate partners (Table 5). 
Table 3. Associations between violence with paying partners and unprotected sex with paying partners $(N=222)$.

\begin{tabular}{lccc}
\hline & $\begin{array}{c}\text { Number of times of } \\
\text { unprotected vaginal } \\
\text { or anal sex with } \\
\text { paying partners in the } \\
\text { past } 90 \text { days }(\text { IRR, } \\
95 \% \mathrm{CI})\end{array}$ & $\begin{array}{c}\text { Proportion of } \\
\text { unprotected vaginal } \\
\text { or anal sex with } \\
\text { paying partners in the } \\
\text { past } 90 \text { days }(\mathrm{b}, \\
95 \% \mathrm{CI})\end{array}$ & $\begin{array}{c}\text { Any unprotected } \\
\text { vaginal or anal sex } \\
\text { with paying partners } \\
\text { in the past } 90 \text { days } \\
\text { (RRR, 95\% CI) }\end{array}$ \\
\hline $\begin{array}{c}\text { Any childhood sexual } \\
\text { abuse }\end{array}$ & $1.15[0.76,1.74]$ & $0.03[-0.06,0.12]$ & $1.14[0.95,1.38]$ \\
$\begin{array}{c}\text { Penetrative childhood } \\
\text { sexual abuse }\end{array}$ & $1.29[0.84,1.98]$ & $0.07[-0.02,0.16]$ & $1.20^{*}[1.01,1.42]$ \\
$\begin{array}{c}\text { Recent physical violence } \\
\text { from paying partners }\end{array}$ & $1.22[0.81,1.84]$ & $0.05[-0.03,0.14]$ & $1.21[1.00,1.47]$ \\
$\begin{array}{c}\text { Recent sexual violence } \\
\text { from paying partners }\end{array}$ & $1.52^{*}[1.00,2.30]$ & $0.12^{* *}[0.03,0.21]$ & $1.34 * *[1.13,1.59]$ \\
\hline
\end{tabular}

Note: Analyses are adjusted for age, education, income, marital status and alcohol use. $* p<0.05 ; * * p<0.01$.

However, the effect was in the opposite direction of what was hypothesised. CSA was positively associated with recent unprotected sex with intimate partners $(p=0.055)$. Similarly, recent sexual violence from an intimate partner was positively associated with recent unprotected sex with an intimate partner $(p<0.05)$. However, the magnitude of the interaction term between recent sexual violence and CSA, while significant, was less than 1 indicating that FSWs who reported both CSA and recent sexual violence from intimate partners had reduced risk of recent unprotected sex with an intimate partner, compared with what would be expected in the absence of effect modification.

Table 4. Associations between violence with intimate partners and unprotected sex with intimate partners $(N=98)$.

\begin{tabular}{lccc}
\hline & $\begin{array}{c}\text { Number of times of } \\
\text { unprotected vaginal } \\
\text { or anal sex with } \\
\text { intimate partners in } \\
\text { the past } 90 \text { days } \\
\text { (IRR, 95\% CI) }\end{array}$ & $\begin{array}{c}\text { Proportion of } \\
\text { unprotected vaginal } \\
\text { or anal sex with } \\
\text { intimate partners in } \\
\text { the past } 90 \text { days }(b, \\
95 \% \text { CI })\end{array}$ & $\begin{array}{c}\text { Any unprotected } \\
\text { vaginal or anal sex } \\
\text { with intimate } \\
\text { partners in the past } \\
90 \text { days (RRR, } \\
95 \% \text { CI) }\end{array}$ \\
\hline $\begin{array}{c}\text { Any childhood sexual } \\
\text { abuse }\end{array}$ & $1.16[0.89,1.52]$ & $0.13[-0.02,0.27]$ & $1.12[0.98,1.29]$ \\
$\begin{array}{c}\text { Penetrative childhood } \\
\text { sexual abuse }\end{array}$ & $1.06[0.79,1.43]$ & $0.06[-0.09,0.23]$ & $1.08[0.94,1.25]$ \\
$\begin{array}{c}\text { Recent physical violence } \\
\text { from intimate partners }\end{array}$ & $1.09[0.82,1.44]$ & $0.06[-0.10,0.22]$ & $1.04[0.92,1.18]$ \\
$\begin{array}{c}\text { Recent sexual violence } \\
\text { from intimate partners }\end{array}$ & $0.78[0.54,1.15]$ & $-0.11[-0.31,0.09]$ & $1.11[0.96,1.29]$ \\
\hline
\end{tabular}

Note: Analyses are adjusted for age, education, income, marital status and alcohol use. 
Table 5. Modification of associations between violence and unprotected vaginal or anal sex with intimate partners by CSA $(N=98)$.

\begin{tabular}{lccc}
\hline & $\begin{array}{c}\text { Number of times of } \\
\text { unprotected vaginal } \\
\text { or anal sex with } \\
\text { intimate partners in } \\
\text { the past } 90 \text { days } \\
\text { (IRR, 95\% CI) }\end{array}$ & $\begin{array}{c}\text { Proportion of } \\
\text { unprotected vaginal } \\
\text { or anal sex with } \\
\text { intimate partners in } \\
\text { the past } 90 \text { days }(b, \\
95 \% \text { CI) }\end{array}$ & $\begin{array}{c}\text { Any unprotected } \\
\text { vaginal or anal sex } \\
\text { with intimate } \\
\text { partners in the past } \\
90 \text { days (RRR, } \\
95 \% \text { CI) }\end{array}$ \\
\hline $\begin{array}{c}\text { Any childhood sexual } \\
\text { abuse }\end{array}$ & $1.20[0.83,1.74]$ & $0.17[-0.03,0.37]$ & $1.15[0.94,1.40]$ \\
$\begin{array}{c}\text { Recent physical violence } \\
\text { from intimate partners }\end{array}$ & $1.14[0.75,1.72]$ & $0.11[-0.12,0.33]$ & $1.06[0.84,1.36]$ \\
$\begin{array}{c}\text { Any CSA } \times \text { recent } \\
\text { physical violence }\end{array}$ & $0.93[0.54,1.61]$ & $-0.07[-0.37,0.22]$ & $0.97[0.73,1.29]$ \\
$\begin{array}{c}\text { Any childhood sexual } \\
\text { abuse }\end{array}$ & $1.20[0.90,1.60]$ & $0.16[-0.005,0.32]$ & $1.16^{*}[1.00,1.36]$ \\
$\begin{array}{c}\text { Recent sexual violence } \\
\text { from intimate partners }\end{array}$ & $0.70[0.34,1.41]$ & $-0.12[-0.46,0.22]$ & $1.31^{* *}[1.08,1.58]$ \\
$\begin{array}{c}\text { Any CSA } \times \text { recent sexual } \\
\text { violence }\end{array}$ & $1.09[0.48,2.48]$ & $-0.04[-0.45,0.37]$ & $0.75^{* *}[0.60,0.95]$ \\
\hline
\end{tabular}

Note: Analyses are adjusted for age, education, income, marital status and alcohol use.

$* p=0.055 ; * *<0.05$.

\section{Discussion}

FSWs in Mongolia reported high prevalence of physical and sexual violence and CSA. The prevalence of violence among sex workers was higher than those among the general population of women in Mongolia (Oyunbileg, Sumberzul, Udval, Wang, \& Janes, 2009). Such high prevalence of violence is consistent with studies of FSWs in other parts of the world. For example, Stachowiak et al. (2005) found that $82 \%$ of sex workers in Moscow had ever experienced physical violence from paying partners. The prevalence of childhood sexual violence in South Africa (60\%) and the USA (53\%) was similar to the 55\% reported in this study (Surratt et al., 2005; Wechsberg et al., 2005). However, caution is indicated when comparing the prevalence of violence across studies due to differences in measuring and collecting data. Few studies have looked at violence against FSWs by intimate partners, particularly at lifetime prevalence by intimate partners (Deering et al., 2014). Reported prevalence of lifetime physical and sexual violence from a paying partner, while somewhat similar to other studies, could be interpreted as higher as many studies tend to combine violence by paying and intimate partners, whereas the current study disaggregated violence by partner type.

Surveys have found IPV to affect $20-30 \%$ of women and families in Mongolia (Open Society Institute, 2006; UNIFEM, 2007). However, gaps in data remain and the need for nationwide surveillance of IPV persists (Deering et al., 2014). The Law against Domestic Violence, enacted in 2005, aims to protect victims and prescribe programmes and prevention activities. While much progress has been made in Mongolia on addressing IPV, significant unmet needs remain including the training of law enforcement officials on the new domestic violence law and expanding services for survivors (UNIFEM, 2007). 
Findings show that penetrative CSA was associated with behaviours that put women at high risk for HIV with paying partners. Results suggest the association between CSA and HIV sexual risk behaviour may vary by CSA severity (i.e. penetrative vs. nonpenetrative). This finding supports previous research that found more severe forms of CSA more strongly associated with later sexual re-victimisation (Classen et al., 2005).

Recent sexual violence was associated with having engaged in unprotected sex with paying partners, but not intimate partners. CSA was found to modify the relationship between recent sexual violence and unprotected sex among intimate partners, but not paying partners. Given the relatively small sample size caution should be used in interpreting these findings. These results are consistent with recent evidence that suggests associations between violence and HIV sexual risk behaviours differ by perpetrator (Decker et al., 2012). More research is needed to understand how and why relationships between violence in childhood and adulthood and sexual risk behaviours differ across perpetrator types. Such findings may point to the need for intervention components which can be tailored to the type of trauma, age of first trauma, duration and intensity of trauma, or perpetrator type, all of which can have important implications for interventions seeking to improve the health and safety of FSWs. The effectiveness of risk reduction interventions likely differs based on many such variables, including the context in which the violence occurs and partner type. Violence prevention and risk reduction intervention strategies should be adapted to various settings in which FSWs experience violence and consider if or when interventions should target not only FSWs but also their partners. Additional research is warranted to further understanding of the relationship between sexual victimisation in childhood and adulthood and sexual risk behaviours, separately by type of perpetrator, among FSWs.

Study findings must be considered in light of several limitations. First, data are crosssectional. As such, no conclusions can be drawn as to the causal nature of the relationships identified in the data. Second, the sample was limited to women in Ulaanbaatar. Experiences and behaviours of FSWs in Ulaanbaatar may differ from those outside the capital city. Third, all FSWs in this study were involved with NAF of Mongolia. Thus, women in this sample may be more knowledgeable about and less likely to engage in HIV risk behaviours than FSWs not involved with NAF. If so, data may underestimate HIV risk behaviours among FSWs in Mongolia. Fourth, this sample was limited to FSW that screened positive for harmful alcohol use. Alcohol use has been linked to increased sexual risk behaviour (Cook \& Clark, 2005; Weinhardt \& Carey, 2000). It is possible that these data overestimate sexual risk behaviours and risk behaviours among FSWs in the general population would be less common than found in this sample.

Despite such limitations, these findings highlight an urgent need for a number of health and mental health services in Mongolia. Mongolia is poised to avoid a large-scale HIV epidemic if adequate prevention education and programming is brought to high-risk groups and the general population in a timely manner. Although HIV prevalence remains low, given the constellation of individual, geographic and economic risk factors, in the absence of adequate programming, it is likely that HIV will become more prevalent both in high-risk groups and the general population. Findings indicate a need for integrated risk reduction services for this highly vulnerable population. Adequate programming requires consideration of the gender and power contexts in which HIV risk taking among women occurs. In the case of FSWs, it is clear that their current and past experiences of sexual violence contribute to sexual risk taking with paying partners. This study supports previous literature indicating that for women, power and dominance are major barriers to 
advocating for safer behaviours and traditional sexual risk reduction skill-building programmes may not adequately protect these women. Programmes are needed that appropriately incorporate and address women's past and current trauma and mental health sequelae, better enabling them to increase self-efficacy in the enactment of safer sex skills. As the first survey of the relationship between violence and sexual risk among FSWs in Mongolia, these results suggest a critical need for trauma-based support services for FSWs. Trauma-based support services may promote improved mental health and safer behaviours among women. Further, given the high prevalence of physical and sexual violence against FSWs, and our understanding of the roles gender and power play in inhibiting women's capacity to reduce risk for HIV in heterosexual relationships, primary prevention efforts that target male perpetrators of such violence are also warranted. Research is needed to further our understanding of paying and intimate partners of FSWs and inform effective interventions to prevent partners from perpetrating violence against FSWs. Such efforts are consistent with a growing interest in Mongolia to address issues of violence (Advocates for Human Rights, 2012). The timing may be right in support of such initiatives in the public health and social work sectors.

\section{Note}

1. Because the sample size for intimate partners is 98 and the sample size for paying partners is 222 , the analyses are limited to estimating the association of violence from intimate partners and sexual behaviours with intimate partners $(n=98)$, and the association of violence from paying partners and sexual behaviours with paying partners $(n=222)$. Analyses do not combine intimate and paying partners.

\section{References}

Adimora, A. A., Ramirez, C., Auerbach, J. D., Aral, S. O., Hodder, S., Wingood, G., ... Bukusi, E. A. (2013). Preventing HIV infection in women. Journal of Acquired Immune Deficiency Syndrome, 63(Suppl 2), S168-S173. doi:10.1097/QAI.0b013e318298a166

Advocates for Human Rights. (2012). Violence against women in Mongolia. Retrieved from http:// www.stopvaw.org/mongolia.

Anderson, R. M. (1999). Transmission dynamics of sexually transmitted infections. In K. Holmes, P. F. Sparling, P. Mardh, S. M. Lemon, W. E. Stamm, ... J. N. Wasserheit (Eds.), Sexually transmitted diseases (3rd ed., pp. 25-37). New York: McGraw Hill.

Carlson, C. E., Chen, J., Cheng, M., Batsukh, A., Toivgoo, A., Reidel, M., \& Witte, S. S. (2012). Reducing sexual HIV/STI risk and harmful alcohol use among women who exchange sex in Mongolia: Results from a randomized clinical trial. Journal of Interpersonal Violence, 27, 19111931. doi:10.1177/0886260511431439

Carlson, C. E., Tsai, L. C., Aira, T., Riedel, M., \& Witte, S. S. (in press). Risks and resiliency of women engaged in sex work in Mongolia. In M. McClelland \& V. Mackie, (Eds.), Routledge handbook of sexuality studies in East Asia. (pp. 305-315). New York: Routledge.

Chersich, M. F., Luchters, S. M., Malonza, I. M., Mwarogo, P., King'ola, N., \& Temmerman, M. (2007). Heavy episodic drinking among Kenyan female sex workers is associated with unsafe sex, sexual violence and sexually transmitted infections. International Journal of STD \& AIDS, 18, 764-769. doi:10.1258/095646207782212342

Choi, S., Chen, K., \& Jiang, Z. (2008). Client-perpetuated violence and condom failure among female sex workers in southwestern China. Sexually Transmitted Diseases, 35(2), 141-146. doi:10.1097/OLQ.0b013e31815407c3

Classen, C., Palesh, O., \& Aggarwal, R. (2005). Sexual revictimization: A review of the empirical literature. Trauma, Violence, \& Abuse, 6(2), 103-129. doi:10.1177/1524838005275087

Cook, R. L., \& Clark, D. B. (2005). Is there an association between alcohol consumption and sexually transmitted diseases? A systematic review. Sexually Transmitted Diseases, 32(3), 156164. doi:10.1097/01.olq.0000151418.03899.97 
Davaalkham, J., Unenchimeg, P., Baigalmaa, C., Oyunbileg, B., Tsuchiya, K., Hachiya, A, ... Oka, S. (2009). High-risk status of HIV-1 infection in the very low epidemic country, Mongolia, 2007. International Journal of STD \& AIDS, 20, 391-394. doi:10.1258/ijsa.2008.008376

Decker, M. R., McCauley, H. L., Phuengsamran, D., Janyam, S., Seage, G. R., III, \& Silverman, J. G. (2010). Violence victimisation, sexual risk and sexually transmitted infection symptoms among female sex workers in Thailand. Sexually Transmitted Infections, 86, 236-240. doi:10.1136/sti.2009.037846

Decker, M. R., Wirtz, A. L., Baral, S. D., Peryshkina, A., Mogilnyi, V., Weber, R. A., ... Beyrer, C. (2012). Injection drug use, sexual risk, violence and STI/HIV among Moscow female sex workers. Sexually Transmitted Infections, 88, 278-283. doi:10.1136/sextrans-2011-050171

Deering, K. N., Amin, A., Shoveller, J., Nesbitt, A., Garcia-Moreno, C., Duff, P., ... Shannon, K. (2014). A systematic review of the correlates of violence against sex workers. American Journal of Public Health, 104(5), e42-e54. doi:10.2105/AJPH.2014.301909

Dunkle, K., Jewkes, R., Brown, H., Yoshihama, M., Gray, G., McIntyre, J., \& Harlow, S. (2004). Prevalence and patterns of gender based violence and revictimization among women attending antenatal clinics in Soweto, South Africa. American Journal of Epidemiology, 160, 230-239. doi:10.1093/aje/kwh194

El-Bassel, N., Witte, S. S., Gilbert, L., Wu, E., Chang, M., Hill, J., \& Steinglass, P. (2003). The efficacy of a relationship-based HIV/STD prevention program for heterosexual couples. American Journal of Public Health, 93, 963-969. doi:10.2105/AJPH.93.6.963

Elbright, J., Altantsetseg, T., \& Oyungerel, R. (2003). Emerging infectious diseases in Mongolia. Emerging Infectious Diseases, 9, 1509-1515. doi:10.3201/eid0912.020520

Fages, V. (1999). Migration and AIDS in South Africa: A public health issue. Pretoria: UNAIDS.

Fanslow, J. L., Robinson, E., Crengle, S., \& Perese, L. (2007). Prevalence of child sexual abuse reported by a cross-sectional sample of New Zealand women. Child Abuse \& Neglect, 31, 935945. doi:10.1016/j.chiabu.2007.02.009

Fergusson, D., Horwood, J., \& Lynskey, M. (1997). Childhood sexual abuse, adolescent sexual behaviours, and sexual revictimization. Child Abuse \& Neglect, 21, 789-803. doi:10.1016/ S0145-2134(97)00039-2

Finkelhor, S. D. (1978). Sexually victimized children and their families. New Hampshire: University of New Hampshire.

Foti, S. M. (1995). Child sexual abuse as a precursor to prostitution. Dissertation Abstracts International: Section B: The Sciences \& Engineering, 55(8-B), 3586.

Hagan, J., \& Dulmaa, N. (2007). Risk factors and prevalence of HIV and sexually transmitted infections among low-income female commercial sex workers in Mongolia. Sexually Transmitted Diseases, 34(2), 83-87. doi:10.1097/01.olq.0000237670.59140.0f

James, J., \& Meyerding, J. (1977). Early sexual experience as a factor in prostitution. Archives of Sexual Behavior, 7(1), 31-42. doi:10.1007/BF01541896

Karandikar, S., \& Prospero, M. (2010). From client to pimp: Male violence against female sex workers. Journal of Interpersonal Violence, 25(2), 257-273. doi:10.1177/0886260509334393

Lalor, K., \& McElvaney, R. (2010). Child sexual abuse, links to later sexual exploitation/high risk sexual behavior and prevention/treatment programs. Trauma, Violence \& Abuse, 11(4), 159-177. doi: $10.1177 / 1524838010378299$

Li, Q., Li, X., \& Stanton, B. (2010). Alcohol use among female sex workers and male clients: An integrative review of global literature. Alcohol and Alcoholism, 45(2), 188-199. doi:10.1093/ alcalc/agp095

Markosyan, K. M., Babikian, T., DiClemente, R. J., Hirsch, J. S., Grigoryan, S., \& del Rio, C. (2007). Correlates of HIV risk and preventive behaviors in Armenian female sex workers. AIDS \& Behavior, 2, 325-334. doi:10.1007/s10461-006-9147-x

Messman-Moore, T., \& Long, P. J. (2003). The role of childhood sexual abuse sequelae in the sexual revictimization of women: An empirical review and theoretical reformulation. Clinical Psychology Review, 23, 537-571. doi:10.1016/S0272-7358(02)00203-9

Ministry of Health of the People's Republic of China. (2012). 2012 China AIDS response Progress Report. Retrieved from http://www.unaids.org/en/dataanalysis/knowyourresponse/countryprogressreports/2012countries/ce CN Narrative Report[1].pdf

Morris, C. N., \& Ferguson, A. G. (2006). Estimation of the sexual transmission of HIV in Kenya and Uganda on the trans-Africa highway: The continuing role for prevention in high risk groups. Sexually Transmitted Infections, 82, 368-371. doi:10.1136/sti.2006.020933 
National AIDS Foundation [NAF]. (2001). HIV and drug use participatory situation assessment report. Ulaanbaatar, Mongolia: NAF/UNDCP/HIV Alliance.

NAF. (2003). Summary of review and evaluation of STI/HIV/AIDS community projects implemented by NGOs/CBOs in 2003. Ulaanbaatar, Mongolia: Author.

Nishigaya, K. (2002). Female garment factory workers in Cambodia: Migration, sex work and HIV/ AIDS. Women's Health, 35(4), 27-42. doi:10.1300/J013v35n04_03

Open Society Institute. (2006). Violence against women: Does the government care in Mongolia? Fact sheet.

Open Society Institute. (2009). Arrest the violence: Human rights abuses against sex workers in Central and Eastern Europe and Central Asia. Sex Workers' Rights Advocacy Network. Retrieved from http://www.opensocietyfoundations.org/sites/default/files/arrest-violence-20091217.pdf

Oyunbileg, S., Sumberzul, N., Udval, N., Wang, J. D., \& Janes, C. R. (2009). Prevalence and risk factors of domestic violence among Mongolian women. Journal of Women's Health, 18, 18731880. doi:10.1089/jwh.2008.1226

Paone, D., Cooper, H., Alperen, J., Shi, Q., \& Des Jarlais, D. (1999). HIV risk behaviours of current sex workers attending syringe exchange: The experiences of women in five US cities. AIDS Care, 11, 269-280. doi:10.1080/09540129947910

Potter, K., Martin, J., \& Romans, S. (1999). Early developmental experiences of female sex workers: A comparative study. Australian \& New Zealand Journal of Psychiatry, 33, 935-940. doi:10.1046/j.1440-1614.1999.00655.x

Purevdawa, E., Moon, T., Baigalmaa, C., Davaajav, K., Smith, M., \& Vermund, S. (1997). Rise in sexually transmitted diseases during democratization and economic crisis in Mongolia. International Journal of STD \& AIDS, 8, 398-401. doi:10.1258/0956462971920190

Rhodes, T., Simic, M., Baros, S., Platt, L., \& Zikic, B. (2008). Police violence and sexual risk among female and transvestite sex workers in Serbia: Qualitative study. BMJ, 337, a811. doi:10.1136/bmj.a811

Rogers, S. J., Ying, L., Xin, Y. T., Fung, K., \& Kaufman, J. (2002). Reaching and identifying the STD/HIV risk of sex workers in Beijing. AIDS Education \& Prevention, 14, 217-227. doi:10.1521/aeap.14.3.217.23892

Rubin, D. B. (1987). Multiple imputation for nonresponse in surveys. New York: Wiley Publications.

Saunders, J. B., Aasland, O. G., Babor, T. F., DeLaFuente, J. R., \& Grant, M. (1993). Development of the alcohol use disorders identification test (AUDIT): WHO collaborative project on early detection of persons with harmful alcohol consumption-II. Addiction, 88, 791-804. doi:10.1111/ j.1360-0443.1993.tb02093.x

Scorgie, F., Chersich, M. F., Ntaganira, I., Gerbase, A., Lule, F., \& Lo, Y. R. (2012). Sociodemographic characteristics and behavioral risk factors of female sex workers in Sub-Saharan Africa: A systematic review. AIDS \& Behavior, 16, 920-933. doi:10.1007/s10461-011-9985-z

Sgroi, S. M. (1982). Handbook of clinical intervention in child sexual abuse. Lexington, MA: D.C. Heath and Company.

Shahmanesh, M., Wayal, S., Copas, A., Patel, V., Mabey, D., \& Cowan, F. (2009). A study comparing sexually transmitted infections and HIV among ex-red-light district and non-red-light district sex workers after the demolition of Baina red-light district. Journal of Acquired Immune Deficiency Syndromes, 52, 253-257. doi:10.1097/QAI.0b013e3181ab6d75

Simic, M., \& Rhodes, T. (2009). Violence, dignity and HIV vulnerability: Street sex work in Serbia. Sociology of Health and Illness, 31(1), 1-16. doi:10.1111/j.1467-9566.2008.01112.x

Sobell, L. C., \& Sobell, M. B. (1992). Timeline follow-back: A technique for assessing selfreported alcohol consumption. In R. Z. Litten \& J. P. Allen (Eds.), Measuring alcohol consumption: Psychosocial and biochemical methods (pp. 41-72). Totowa, NJ: Humana Press.

Stachowiak, J. A., Sherman, S., Konakova, A., Krushkova, I., Beyrer, C., Peryskina, A., \& Strathdee, S. (2005). Health risks and power among female sex workers in Moscow. SIECUS Report, 33(2), 18-25.

Straus, M. A., Hamby, S. L., Boney-McCoy, S., \& Sugarman, D. B. (1996). The revised conflict tactics scales (CTS2): Development \& preliminary psychometric data. Journal of Family Issues, 17, 283-316. doi:10.1177/019251396017003001

Surratt, H. L., Kurtz, S. P., Weaver, J. C., \& Inciardi, J. A. (2005). The connections of mental health problems, violent life experiences, and the social milieu of the "stroll" with the HIV risk 
behaviours of female street sex workers. Journal of Psychology \& Human Sexuality, 17(1/2), 23-44. doi:10.1300/J056v17n01 03

Swain, S. N., Saggurti, N., Battala, M., Verma, R. K., \& Jain, A. K. (2011). Experience of violence and adverse reproductive health outcomes, HIV risks among mobile female sex workers in India. BMC Public Health, 11, 357. doi:10.1186/1471-2458-11-357

Ulibarri, M., Semple, S., Rao, S., Strathdee, S., Fraga-Vallejo, M., Bucardo, J., ... Patterson, T. (2009). History of abuse and psychological distress symptoms among female sex workers in two Mexico-U.S. border cities. Violence and Victims, 24, 399-413. doi:10.1891/0886-6708.24.3.399

Ulibarri, M. D., Strathdee, S. A., Ulloa, E. C., Lozada, R., Fraga, M. A., Magis-Rodríguez, C., ... Patterson, T. L. (2011). Injection drug use as a mediator between client-perpetrated abuse and HIV status among female sex workers in two Mexico-US border cities. AIDS and Behavior, 15(1), 179-185. doi:10.1007/s10461-009-9595-1

UNAIDS. (2001). Population mobility and AIDS: UNAIDS technical update. Geneva: United Nations.

UNAIDS. (2011). World AIDS Day report. Geneva: United Nations. Retrieved from http://www. unaids.org/en/media/unaids/contentassets/documents/unaidspublication/2011/JC2216_WorldAIDS day_report_2011_en.pdf

UNAIDS Mongolia. (2012). Mongolia Joint United Nations Programme on AIDS 2007-2011 Report. UNAIDS Mongolia: Ulaanbaatar, Mongolia. Retrieved from http://hivhealthclearing house.unesco.org/sites/default/files/media/content/migrated/user/pdf/2012/JUNTA_2007-2011_ Report_FINAL_3_.pdf

UNGASS. (2010). UNGASS country progress report: Mongolia. New York: United Nations General Assembly.

UNICEF. (2006). Country report: Mongolia: East Asia and Pacific regional consultation. Washington, DC: Author.

UNIFEM. (2007). A life free of violence is our right! Mongolia country profile. UNIFEM.

Wechsberg, W. M., Luseno, W. K., \& Lam, W. K. (2005). Violence against substance-abusing southern African sex workers: Intersection with culture and HIV risk. AIDS Care, 17(Suppl 1), S55-S64. doi:10.1080/09540120500120419

Wechsberg, W. M., Luseno, W. K., Lam, W. K., Parry, C. D., \& Morojele, N. K. (2006). Substance use, sexual risk, and violence: HIV prevention intervention with sex workers in Pretoria. AIDS \& Behavior, 10(2), 131-137. doi:10.1007/s10461-005-9036-8

Weinhardt, L. S., \& Carey, M. P. (2000). Does alcohol lead to sexual risk behaviour? Findings from event-level research. Annual Review of Sex Research, 11, 125-157. doi:10.1080/10532528.2000. 10559786

Wingood, G., Hunter-Gamble, D., \& DiClemente, R. (1993). A pilot study of sexual communication and negotiation among young African American women: Implications for HIV prevention. Journal of Black Psychology, 19(2), 190-203. doi:10.1177/00957984930192008

Witte, S. S., Altantsetseg, B., Aira, T., Riedel, M., Chen, J., Potocnik, K., ... Yao, H. (2011). Reducing sexual HIV/STI risk and harmful alcohol use among female sex workers in Mongolia: A randomized clinical trial. AIDS \& Behavior, 15, 1785-1794. doi:10.1007/s10461-011-9984-0

World Bank. (2013). Poverty rate came down to 27.4 percent in 2012. Retrieved from http://www. worldbank.org/en/news/press-release/2013/05/21/poverty-rate-came-down-to-27-4-percent-in-2012

World Health Organization [WHO]. (2011). Preventing HIV among sex workers in sub-Saharan Africa: A literature review. Geneva: Author. Retrieved from http://whqlibdoc.who.int/publications/2011/9789241501279_eng.pdf

Yadav, G., Saskin, R., Ngugi, E., Kimani, J., Keli, F., Fonck, K., ... Kaul, R. (2005). Associations of sexual risk taking among Kenyan female sex workers after enrollment in an HIV-1 prevention trial. Journal of Acquired Immune Deficiency Syndrome, 38, 329-334. 